\title{
HAZARDS IN NON-PASTEURIZED MILK ON RETAIL SALE IN BRAZIL: PREVALENCE OF SALMONELLA SPP, LISTERIA MONOCYTOGENES AND CHEMICAL RESIDUES
}

\author{
Luís Augusto Nero ${ }^{1}$; Marcos Rodrigues de Mattos $^{2}$; Vanerli Beloti ${ }^{2}$; Marcia A.F. Barros ${ }^{2}$; Daisy Pontes Netto ${ }^{2}$; \\ José Paes A.N. Pinto ${ }^{3}$; Nélio José de Andrade" Wladimir P. Silva ${ }^{5}$; Bernadette D.G.M. Franco ${ }^{1 *}$
}

${ }^{1}$ Departamento de Alimentos e Nutrição Experimental, Faculdade de Ciências Farmacêuticas, Universidade de São Paulo, São Paulo, SP, Brasil; ${ }^{2}$ Departamento de Medicina Veterinária Preventiva, Universidade Estadual de Londrina, Londrina, PR, Brasil; ${ }^{3}$ Departamento de Higiene Veterinária e Saúde Pública, Faculdade de Medicina Veterinária e Zootecnia, Universidade Estadual Paulista, Botucatu, SP, Brasil; ${ }^{4}$ Departamento de Tecnologia de Alimentos, Universidade Federal de Viçosa, Viçosa, MG, Brasil; ${ }^{5}$ Departamento de Ciências e Tecnologia Agro-Industrial, Universidade Federal de Pelotas, Pelotas, RS, Brasil.

Submitted: May11, 2004; Returned to authors for corrections: October 28, 2004; Approved: November 19, 2004

\begin{abstract}
Fluctuations in the Brazilian milk market force small milk producers to find temporary trade alternatives, which include selling raw milk to people who prefer this type of milk rather than heat-processed milk. Considering the importance of these small milk producers to the market and the well-known health risks associated to consumption of raw milk, this study evaluated the microbiological quality and the presence of Listeria monocytogenes, Salmonella spp., chlorine, antimicrobials and insecticides (organophosphates and carbamates) in raw milk produced in 210 small and medium farms located in four important milk-producing Brazilian states (Paraná, São Paulo, Minas Gerais and Rio Grande do Sul). In 66\% of the selected farms the milking was manual. In $33 \%$ of them, the milking was semi-automatic, and only $1 \%$ were equipped with fully automatic milking systems. All raw milk samples were negative for L. monocytogenes, Salmonella spp and chlorine. Mesophilic aerobes counts were higher than $10^{5} \mathrm{CFU} / \mathrm{ml}$ in $75.7 \%$ of the samples. In $80.4 \%$, coliforms were over $10^{2} \mathrm{CFU} / \mathrm{ml}$. Escherichia coli was detected in $36.8 \%$ of the samples. Insecticides and antimicrobial residues were observed in $74.4 \%$ and $11.5 \%$ of the samples, respectively. The presence of unacceptable levels of hygiene indicators, insecticides and antimicrobial residues were considered more important risk factors than the two pathogens.
\end{abstract}

Key words: hazards, raw milk, Salmonella, Listeria monocytogenes, hygiene indicators, insecticides, antimicrobials

\section{INTRODUCTION}

In 2002, Brazil produced, 23.3 million tons of fluid milk, which corresponds to $32.3 \%$ of the milk produced in South America and $4.7 \%$ of the milk produced in the world (7). Twenty to forty percent of the milk produced in the country come from small/ medium milk-producing farms, which current estimated number is close to one million. These farms produce 50-500 L/day, and their production is destined to cooperatives, which intermediate the transfer of the refrigerated raw milk to large milk processing companies (13).

Due to fluctuations in the Brazilian milk market, the small milk producers need to find temporary trade alternatives, which include selling raw milk to people who prefer this type of milk rather than heat-processed milk. Despite unlawful (4), retail sale of raw milk for human consumption is an important market alternative because there is a well-established demand for nonpasteurized milk in the country (13). In 1999, a Brazilian

*Corresponding author. Mailing address: Departamento de Alimentos e Nutrição Experimental, Faculdade de Ciências Farmacêuticas, Universidade de São Paulo, Av. Prof. Lineu Prestes, 580, Bloco 13B, Cidade Universitária. 05508-900, São Paulo, SP, Brasil. Tel.: (+5511) 3091-2191. Fax: (+5511) 3815-4410. E-mails: bfranco@usp.br (B.G.D.M. Franco); luisnero@yahoo.com.br (L.A. Nero) 
consultancy institution conducted an interesting survey among 1154 individuals living in rural areas in four major Brazilian milkproducing regions aiming to collect information about the reasons for their preference for raw milk rather than pasteurized milk. Sixty one percent of the interviewed individuals alleged that raw milk is "stronger", "more nutritive", "more natural", "more fatty" and "more reliable because has no added water or chemicals". Other twenty four percent of interviewed persons informed that buy raw milk because it is cheaper. Ease of access to the product was also cited as decisive factor (24).

It is well known that consumption of raw milk can be life threatening and many foodborne disease outbreaks were already traced to this product $(3,11,17,28)$. The literature is plenty of data on diseases caused by pathogenic microorganisms like Listeria monocytogenes and Salmonella associated to raw milk or raw milk based dairy products $(6,12,14,18,19,20,25)$. Data concerning foodborne diseases caused by raw milk and derivatives in Brazil are inconsistent (10). In counterpart, only limited data are available about the occurrence of foodborne pathogens in Brazilian raw milk $(2,21,26)$, and their involvement in milkborne diseases outbreaks is unknown. In addition to microbiological hazards, chemical components, like antibiotics, insecticides and pesticides used in inadequate farming practices, pose an extra hazard to the consumer health.

According to the Brazilian Institute of National Statistics and Geography, 35.6 to $42.0 \%$ of the milk produced in the country between 1998 and 2001 was not inspected by any federal, state or municipal sanitary inspection authority (Table 1) (15). It is more likely that milk produced by small farmers belong to this group than milk produced by large and well-established milk producers. Considering that non-inspected milk may contain several health hazardous agents, and considering the importance of the small milk producers to the Brazilian milk market, this study intended to evaluate the health risks associated to consumption of raw milk produced in selected small farms located in four out of the five most important milk-producing states in Brazil. The studied risk factors included Listeria monocytogenes, Salmonella spp., chlorine, antimicrobials and insecticides (organophosphates and carbamates).

Table 1. Milk production in Brazil (1998-2001), in billion liters.

\begin{tabular}{lrrrrr}
\hline & \multicolumn{4}{c}{ Years } & \multirow{2}{*}{ Average } \\
\cline { 2 - 5 } & 1998 & 1999 & 2000 & 2001 & \\
\hline Produced & 18,984 & 19,070 & 19,767 & 20,510 & 19,578 \\
Inspected & 10.995 & 11.139 & 12.108 & 13.213 & 11.864 \\
Deficit & 7.969 & 7.931 & 7.659 & 7.292 & 7.714 \\
& $(42.0 \%)$ & $(41.6 \%)$ & $(38.7 \%)$ & $(35.6 \%)$ & $(39.4 \%)$ \\
\hline
\end{tabular}

Source: IBGE, 2004.

\section{MATERIALS AND METHODS}

\section{Selection of milk producing farms}

Based on differences in farming practices and milking equipment, 210 milk-producing farms were selected in the four most important milk producing states in Brazil: Minas Gerais (MG), Rio Grande do Sul (RS), Paraná (PR) and São Paulo (SP). The location of the states in the country is shown in Fig. 1. The selected farms produced 50 to 500 liters of milk per day, being classified as small to medium producers. The farms were located in the vicinity of the cities of Viçosa - MG (47 farms), Pelotas RS (50 farms), Londrina - PR (63 farms) and Botucatu - SP (50 farms). In $139(66.2 \%)$ of them, the milking was manual and in 69 (32.8\%) the milking was semi-automatic, i.e., a vacuum milking machine removed the milk from the animals and then the milkman mixed the milk from different cans and cooled the mixture in horizontal refrigerators. In only two farms (1\%) the milking process was fully automatic.

\section{Collection of milk samples}

In each farm, approximately $100 \mathrm{ml}$ of milk were withdrawn from the final container and sent to the laboratory under refrigeration. Microbiological testing was done in less than two hours and then samples were then frozen at $-18^{\circ} \mathrm{C}$ until tested for chemical residues.

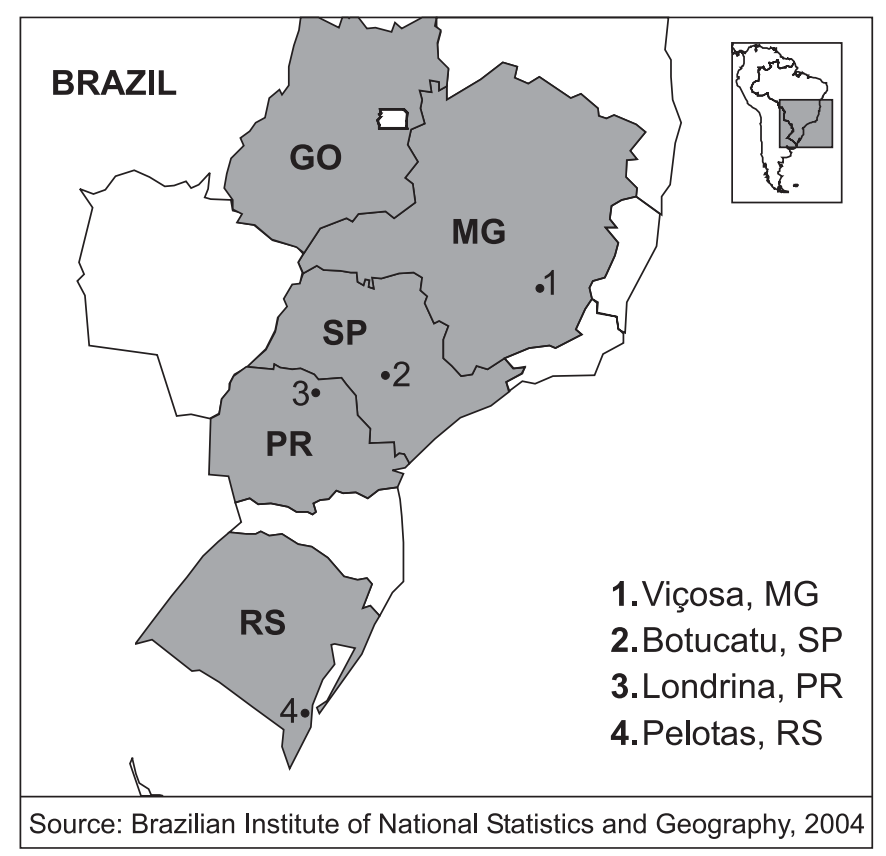

Figure 1. Main milk producing states in Brazil (GO: Goiás, MG: Minas Gerais, SP: São Paulo, PR: Paraná and RS: Rio Grande do Sul). 


\section{Detection of Salmonella}

The APHA method, as described by Flowers, Andrews, Donnely and Koenig (9) with modifications, was used. Twentyfive $\mathrm{mL}$ of milk were homogenized with $225 \mathrm{~mL}$ Lactose Broth and incubated for $24 \mathrm{~h}$ at $35^{\circ} \mathrm{C}$. One hundred $1 / 4 \mathrm{~L}$ of this broth were transferred to Rappaport-Vassiliadis Broth and incubated for $24 \mathrm{~h}$ at $42^{\circ} \mathrm{C}$. One $\mathrm{mL}$ of the lactose broth was also transferred to Kaufman's Tetrationate Broth and incubated for $24 \mathrm{~h}$ at $35^{\circ} \mathrm{C}$. Both broths were then streaked on Bismuth Sulphite Agar, XLD Agar and Hectoen Enteric Agar plates and incubated for 24h at $35^{\circ} \mathrm{C}$. When suspect Salmonella colonies were present, they were transferred to TSI and LIA agar slants and incubated for $24 \mathrm{~h}$ at $35^{\circ} \mathrm{C}$. Salmonella indicative results were confirmed through serological tests, using somatic and flagellar polyvalent antisera. All culture media were from Oxoid Ltd, UK and Salmonella antisera were from Probac do Brasil Produtos Bacteriológicos Ltda.

\section{Detection of Listeria monocytogenes}

The APHA method, as described by Flowers, Andrews, Donnely and Koenig (9) with modifications, was used. Twentyfive milliliters of milk were homogenized with $225 \mathrm{~mL}$ of Listeria Enrichment Broth containing Listeria Selective Enrichment Supplement, and incubated at $30^{\circ} \mathrm{C}$ for $24 \mathrm{~h}$ and $48 \mathrm{~h}$. After incubation, an aliquot was streaked on Oxford and PALCAM agar plates and incubated for $24 \mathrm{~h}$ and $48 \mathrm{~h}$ at $35^{\circ} \mathrm{C}$. When suspect Listeria colonies were present, they were submitted to proper biochemical tests, according to Pagotto, Daley, Farber and Warburton (23). All media were from Oxoid Ltd, UK.

\section{Enumeration of hygiene indicators}

Mesophilic aerobes, total coliforms and Escherichia coli were enumerated using Petrifilm ${ }^{\mathrm{TM}} \mathrm{AC}$ and EC plates (3M do Brasil Ltda). Undiluted and 1:10 and 1:100 diluted milk samples were plated in appropriate Petrifilm ${ }^{\mathrm{TM}}$ plates, incubated and interpreted according to the manufacturer instructions.

\section{Detection of antimicrobials, insecticides and chlorine}

Antimicrobial residues were investigated using CharmTest (Charm Sciences, Inc., USA). Two hundred microliters of each milk sample were transferred to the kit, and incubated in a water-bath at $62^{\circ} \mathrm{C}$ for $2 \mathrm{~h}$ and $45 \mathrm{~min}$. Development of a blue color in the kit was interpreted as a positive result.

Insecticides (carbamates and organophosphates) were detected by thin layer chromatography, as described in AOAC (1).

Chlorine was investigated by adding $1.5 \mathrm{~mL}$ of $7 \%$ Potassium Iodine solution to $5 \mathrm{~mL}$ of raw milk sample (5). Development of a yellow color was interpreted as a positive result.

All tests included positive and negative controls.

\section{RESULTS AND DISCUSSION}

All tested samples were negative for Salmonella and $L$. monocytogenes. Table 2 shows the results according to the geographic origin of the samples. In the majority of the samples (75.7\%), the counts of mesophilic aerobes were above $10^{5} \mathrm{CFU} /$ $\mathrm{mL}$, and in $80.4 \%$ the number of coliforms was higher than $10^{2}$ CFU $/ \mathrm{mL}$. In $29.4 \%$, the counts of E.coli were above $10^{2} \mathrm{CFU} / \mathrm{mL}$.

None of the samples was positive for chlorine but antimicrobials were detected in $11.5 \%$ of the samples. Insecticides (organophosphates and carbamates) were detected in high percentages: their prevalence varied from $42.9 \%$ up to 95.9\% of the milk samples (Table 3).

The samples collected in Viçosa, Minas Gerais, presented a slightly better quality that the ones collected in the other regions (Table 2), which is certainly consequence of the PDPL-RV project (Projeto de Desenvolvimento da Pecuária Leiteira da Região de Viçosa - Development of the Dairy Cattle Production in the Region of Viçosa) implemented in the region, called, a successful joint venture established in 1988 between University of Viçosa and a private enterprise. The main goal of this program is to assist small milk producers, helping them to establish good farming practices, reduce costs and improve the quality of their product (22). It should be also noted that raw milk samples collected in Pelotas, RS, presented the lowest counts of E.coli, indicating better hygiene conditions in that region.

Table 2. Counts of mesophilic aerobes, total coliforms and E. coli in 210 raw milk samples collected in the regions of Londrina PR, Botucatu SP, Viçosa MG and Pelotas RS, Brazil.

\begin{tabular}{crrrrrrrr}
\hline Counts log & \multicolumn{2}{c}{$\begin{array}{c}\text { Londrina } \\
\text { CFU/mL }\end{array}$} & \multicolumn{2}{c}{$\begin{array}{c}\text { Botucatu } \\
\text { PR }\end{array}$} & \multicolumn{2}{c}{$\begin{array}{c}\text { Viçosa } \\
\text { MG }\end{array}$} & \multicolumn{2}{c}{$\begin{array}{c}\text { Pelotas } \\
\text { RS }\end{array}$} \\
\cline { 2 - 9 } & \multicolumn{1}{c}{$\mathrm{n}$} & $\%$ & $\mathrm{n}$ & $\%$ & \multicolumn{1}{c}{$\mathrm{n}$} & $\%$ & $\mathrm{n}$ & $\%$ \\
\hline \multicolumn{2}{c}{ mesophilic aerobes } \\
$<5$ & 17 & 26.98 & 3 & 6.00 & 22 & 46.81 & 9 & 18.00 \\
$5-6$ & 16 & 25.40 & 13 & 26.00 & 16 & 34.04 & 12 & 24.00 \\
$>6$ & 30 & 47.62 & 34 & 68.00 & 9 & 19.15 & 29 & 58.00 \\
Sub total & 63 & 100.00 & 50 & 100.00 & 47 & 100.00 & 50 & 100.00 \\
Total coliforms & & & & & & & \\
$<2$ & 12 & 21.05 & 2 & 4.00 & 15 & 31.91 & 11 & 22.00 \\
$2-3$ & 16 & 28.07 & 24 & 48.00 & 19 & 40.43 & 29 & 58.00 \\
$>3$ & 29 & 50.88 & 24 & 48.00 & 13 & 27.66 & 10 & 20.00 \\
Sub total & 57 & 100.00 & 50 & 100.00 & 47 & 100.00 & 50 & 100.00 \\
E.coli & & & & & & & & \\
$<2$ & 39 & 68.42 & 28 & 56.00 & 35 & 74.47 & 42 & 84.00 \\
$2-3$ & 7 & 12.28 & 10 & 20.00 & 4 & 8.51 & 7 & 14.00 \\
$>3$ & 11 & 19.30 & 12 & 24.00 & 8 & 17.02 & 1 & 2.00 \\
Sub total & 57 & 100.00 & 50 & 100.00 & 47 & 100.00 & 50 & 100.00 \\
\hline
\end{tabular}


Table 3. Prevalence of antimicrobials and insecticides in raw milk samples produced in Londrina - PR, Botucatu - SP, Viçosa - MG and Pelotas - RS.

\begin{tabular}{lcccc}
\hline & \multirow{2}{*}{$\begin{array}{c}\text { Number of } \\
\text { samples }\end{array}$} & antimicrobials & \multicolumn{2}{c}{ insecticides } \\
\cline { 3 - 5 } & & $\mathrm{n}(\%)$ & $\mathrm{n}(\%)$ & $\mathrm{n}(\%)$ \\
\hline Londrina - PR & 63 & $13(20.6)$ & $27(42.9)$ & $46(73.0)$ \\
Botucatu - SP & 49 & $04(8.2)$ & $47(95.9)$ & $27(55.1)$ \\
Viçosa - MG & 47 & $04(8.5)$ & $41(87.2)$ & $40(80.1)$ \\
Pelotas - RG & 50 & $03(6.0)$ & $42(84.0)$ & $41(82.0)$ \\
Total & 209 & $24(11.5)$ & $157(75.1)$ & $154(73.7)$ \\
\hline
\end{tabular}

que dão preferência a esse tipo de leite. Considerando a importância desse mercado e os conhecidos riscos à saúde que o consumo de leite cru pode representar, este estudo avaliou a qualidade microbiológica e a presença de Listeria monocytogenes, Salmonella spp., resíduos de cloretos, antimicrobianos e inseticidas (organofosforados e carbamatos) em leite cru produzido em 210 propriedades leiteiras localizadas em quatro importantes estados produtores de leite no Brasil (Paraná, São Paulo, Minas Gerais e Rio Grande do Sul). Em 66\% das propriedades selecionadas, a ordenha era manual. Em $33 \%$ a ordenha era semiautomática (ordenha mecânica balde ao pé) e

Negative results for Salmonella or Listeria detected in this study indicate that the presence of unacceptable levels of hygiene indicators, insecticides and antimicrobial residues are more important risk factors than Salmonella spp and Listeria monocytogenes in milk produced by Brazilian small milk producers. However, these results should be interpreted with care because negative results for the two pathogens may not reflect reality. A high percentage of samples were positive for antimicrobials and pesticides (Table 3), and these compounds may have inhibited the growth of the pathogens during enrichment of the samples. In addition, the intense competing flora may have interfered too (16). It is well known that these microorganisms may interfere in the efficiency of the pathogen isolation procedures or induce sub-lethal injury in the pathogens, interfering in their detection. In addition, bacteriocin-producing microrganisms may have also inhibited growth of these pathogens, especially L. monocytogenes (27). Further studies are needed to clarify these interferences, especially because preference for non-processed milk is a worldwide trend (8).

\section{ACKNOWLEDGEMENTS}

The authors thank CAPES and FAPESP (Proc. 01/13076-8) for financial support and for the PhD fellowship to author L.A.Nero. The authors are immensely grateful to $3 \mathrm{M}$ do Brasil Ltda. for donating the Petrifilm plates.

\section{RESUMO}

\section{Perigos em leite não-pasteurizado comercializado no Brasil: ocorrência de Salmonella spp, Listeria monocytogenes e de resíduos químicos}

A instabilidade do mercado de leite no Brasil força pequenos produtores de leite a procurar alternativas de comércio de sua produção, o que inclui a venda de leite cru para indivíduos em apenas $1 \%$ o sistema de ordenha e armazenamento era totalmente mecânico (sistema fechado). Todas as amostras de leite cru foram negativas para L. monocytogenes, Salmonella spp e resíduos de cloretos. As contagens de aeróbios mesófilos foram superiores a $10^{5} \mathrm{UFC} / \mathrm{mL}$ em $75,7 \%$ das amostras. Em 80,4\%, as contagens de coliformes foram superiores a $10^{2} \mathrm{UFC} / \mathrm{mL}$. Escherichia coli foi detectada em $36,8 \%$ das amostras. Inseticidas e resíduos de antibióticos foram observados em 74,4\% e 11,5\% das amostras, respectivamente. Níveis inaceitáveis de microrganismos indicadores de higiene, inseticidas e resíduos de antibióticos foram considerados fatores de risco mais importantes que os dois patógenos estudados.

Palavras-chave: perigos, leite cru, Salmonella, Listeria monocytogenes, indicadores de higiene, inseticidas, antibióticos.

\section{REFERENCES}

1. AOAC. Official Methods of Analysis of AOAC International. 17ed, 2nd rev. AOAC International, Gaithersburg, 2003.

2. Avila, C.R.; Gallo, C.R. Survey of Salmonella in raw milk, pasteurized milk and Minas Frescal cheese commercialized in Piracicaba, Brazil. Scentia Agricola, 53:159-163, 1996.

3. Boor, K.J. Pathogenic microorganisms of concern to the dairy industry. Dairy Food Environ. Sanit., 17:714-717, 1997.

4. Brasil. Decreto-Lei $\mathrm{n}^{\circ} 30.691$, de 29 de março de 1952. Aprova o novo Regulamento da Inspeção Industrial e Sanitária de Produtos de Origem Animal. Diário Oficial da União, Rio de Janeiro, p.10.785, 07 jul. 1952.

5. Brasil. Ministério da Agricultura. LANARA: Métodos Analíticos Oficiais para Controle de Produtos de Origem Animal e seus Ingredientes. II Métodos Físicos e Químicos. Brasília DF, 1981.

6. Buyser, M-L.; Dufour, B.; Maire, M.; Lafarge, V. Implication of milk and milk products in food-borne diseases in France and in different industrialised countries. Int. J. Food Microbiol., 67:1-17, 2001.

7. EMBRAPA. Empresa Brasileira de Agropecuária. Available at http:/ /www.cnpgl.embrapa.br/producao/dados2002/producao/ tabela0212.php [2004 Feb 28].

8. Enticott, G. Risking the rural: nature, morality and the comsumption of unpasteurised milk. J. Rural Stud., 19:411-424, 2003. 
9. Flowers, R.S.; Andrews, W.; Donnelly, C.W.; Koenig, E. Pathogens in milk and milk products. In: Marshall, R. T. (ed). Standard methods for the examination of dairy products. 16th ed. American Public Health Association, Washington, 1993, p.103-211.

10. Franco, B.D.G.M.; Landgraf, M.; Destro, M.T.; Gelli, D. Foodborne diseases in Southern South América. In: Miliotis, M.; Bier, J. (ed.) International Handbook of Foodborne Pathogens. Marcel Dekker, New York, 2003, p.733-743.

11. Franco, R.M.; Cavalcanti, R.M.S.; Wood, P.C.B.; Loretti, V.P.; Gonçalves, P.M.R.; Oliveira, L.A.T. Avaliação da qualidade higiênico-sanitária de leite e derivados. Higiene Alimentar, 14:7077, 2000.

12. Gaya, P.; Sanchez, J.; Medina, M.; Nuñez, M. Incidence of Listeria monocytogenes and other Listeria species in raw milk produced in Spain. Food Microbiol., 15:551-555, 1998.

13. Globo Rural. O desafio do leite. Globo Rural, 220:30-40, 2004.

14. Guerra, M.M.; McLauchlin, J.; Bernardo, F.A. Listeria in ready-toeat and unprocessed foods produced in Portugal. Food Microbiol., $18: 423-429,2001$.

15. IBGE. Instituto Brasileiro de Geografia e Estatística. Available at http://www.ibge.gov.br [2004 Feb 28].

16. Jay, J.M. Foods with low numbers of microorganisms may not be the safest foods OR, why did human listeriosis and hemorrhagic colitis become foodborne diseases? Dairy, Food Environ. Sanit., 15:674677, 1995

17. Jay, J.M. Modern Food Microbiology, 6th ed. Gaithersburg, MD, Aspen, 2000, 854p.

18. Kozak, J.; Balmer, T.; Byrne, R.; Fisher, K. Prevalence of Listeria monocytogenes in food: Incidence in dairy products. Food Control, 7:215-221, 1996
19. Leclerc, V.; Dufour, B.; Lombard, B.; Gauchard, F.; Garin-Bastuji, B.; Salvat, G.; Brisabois, A.; Poumeyrol, M.; Buyser, M-L.; GnanouBesse, N.; Lahellec, C. Pathogens in meat and milk products: surveillance and impact on human health in France. Livest. Prod. Sci., 76:195-202, 2002.

20. Loncarevic, S.; Danielsson-Tham, M.L.; Tham, W. Occurrence of Listeria monocytogenes in soft and semi-soft cheeses in retail outlets in Sweden. Inter. J. Food Microbiol., 26:245-250, 1995.

21. Moura, S.M.; Destro, M.T.; Franco, B.D.G.M. Incidence of Listeria species in raw and pasteurized milk produced in São Paulo, Brazil Inter. J. Food Microbiol, 19:229-237, 1993.

22. PDPL-RV. Programa de Desenvolvimento da Pecuária Leiteira da Região de Viçosa. Available at www.ufv.br/pdpl [2004 Feb 28].

23. Pagotto, F.; Daley, E.; Farber, J.; Warburton, D. Isolation of Listeria monocytogenes from all food and environmental samples. Health Canada's - Government of Canada [on-line] 2001. Available at http://www.hc-sc.gc.ca/food-aliment [2004 Feb 28].

24. Rios Estudos e Projetos. O consumo do leite informal no Brasil. Available at http://www.tetrapak.com.br/ [2004 Feb 28].

25. Rudolf, M.; Scherer, S. High incidence of Listeria monocytogenes in European red smear cheese. Inter. J. Food Microbiol, 63:91-98, 2001

26. Silva, I.M.M.; Almeida, R.C.C.; Alves, M.A.O.; Almeida, P.F Occurrence of Listeria spp. in critical points and the environment of Minas Frescal cheese processing. Inter. J. Food Microbiol, 81:241248, 2001

27. Stecchini, M.L.; Aquili, V.; Sarais, I. Behaviour of Listeria monocytogenes in Mozzarella cheese in presence of Lactococcus lactis. Inter. J. Food Microbiol, 25:301-310, 1995.27.

28. Todd, E.C.D.; Harwing, J. Microbial risk analysis of food in Canada. J. Food Prot., Suppl.:10-18, 1996. 
This article has received corrections in agreement with the ERRATUM published in Volume 35 Number 4. 